\title{
Seeking God's shalom in South African cities through a new glocal togetherness
}

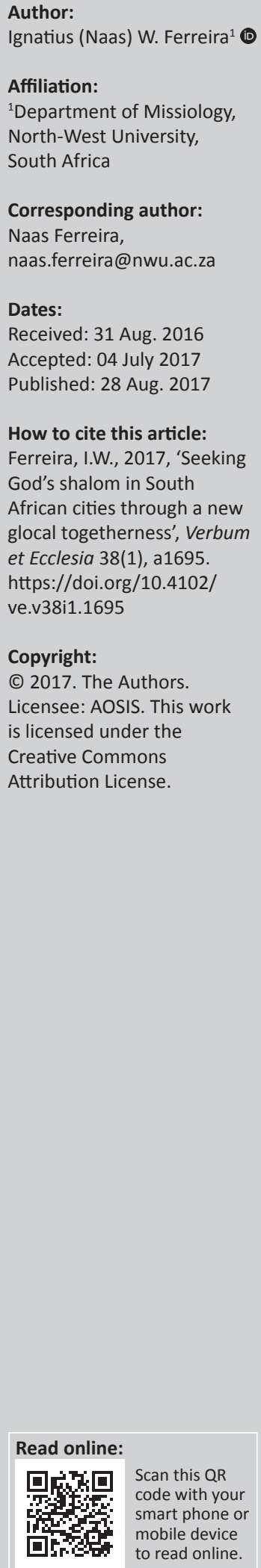

The objective of this article is to clearly reflect the reality of our modern world experiencing the convergence of two mighty movements meeting and flowing into each other. The first stream is the tidal wave of people migrating to the urban centres of our globalising world. The second stream is the result of a massive shift in the centre of Christianity away from its traditional rootedness in Western Christendom. The biggest challenge of our time is for this Christian Church, still stuck in the prevailing Christendom paradigm, to wake up to and actively engage this new post-Christendom context. This article would like to draw specific attention to the South African context where the traditional Western and now developing Southern Christianity find a common Developing World intersection. As 'pilgrims or exiles' that is facing a strange and confronting new world, the Western Church should accept the new missiological challenge that globalisation and urbanisation presents. The Western Church must heed a very urgent call to stay relevant and be actively involved in God's global missio Dei currently unfolding in our world. The only way for the Christian Church to be local instruments of God's Kingdom in a new urban world, is to actively seek a new glocal togetherness.

Intradisciplinary and/or interdisciplinary implications: The Western theological academy needs to urgently engage the social sciences in order to cooperate and collaborate in all areas of urban and social development, urban planning, community development and even urban advocacy for the needs of the urban poor and marginalised. The Christian Church, as God's 'missionary people', is Biblically mandated and spiritually equipped to be actively involved in the urban challenges that globalisation and urbanisation present.

\section{Introduction}

When Thomas Friedman wrote his bestseller book 'The World is Flat' (Friedman 2006), he wanted to emphasise the fact that the globalised world of the 21st century is a very real and confronting new reality. What was unnerving to him was the fact that he realised that this flattening of the world had been taking place while he was 'otherwise engaged' (Friedman 2006:8). What he really meant was that while he was busy with something else, the reality of a flattening world was passing him by completely. This will be the research focus of this article. It will not only focus on the unstoppable and all-inclusive process of globalisation that has connected everything and everybody on a global scale but also on the seeming inability, ignorance or reluctance of the 'traditional' ${ }^{1}$ Christian Church in the Western world, to adequately respond to this in an appropriate way. It must be stated from the onset that globalisation does present the Christian Church with wonderful opportunities (when consciously engaged) but also with very negative consequences (when ignored in any way).

The process of globalisation has set the whole world in motion. This article will firstly focus on the global movement ${ }^{2}$ of people and will convincingly show that the millions of people that are on the move are moving towards the cities of our modern world. A very specific attention, however not exclusive, will be given to the process of urbanisation as it is affecting the context of South Africa.

The second focus of this article will be on another global movement within the processes of globalisation. It will highlight the dramatic shift of the centre of Christianity that moved away from the west to the south. ${ }^{3}$ This shift ultimately heralds the end (the final passing) of Christendom and places the Western Church in a crisis (Dowsett 2001:448). However, this same shift also

\footnotetext{
1.The focus will primarily be on the Christian Church that after Biblical times historically developed in Western Europe and from the fourth century (time of Constantine) became known as 'Christendom'. The history and further growth of this church is also very closely linked to the history and development of Western culture.
}

2.This movement is also called - migration.

3.The West (Christianity that historically developed within the folds of Western culture) and South (a new growth of Christianity independent from the traditional Western setting) 
announces the birth (the new formation) of World Christianity. ${ }^{4}$ Globalisation is producing a 'runaway world' (Giddens 2002:2), and it is shifting our very life circumstances (Giddens 2002:19) by restructuring the way that we live (Giddens 2002:3). This unsettling, fluid, uncertain, confusing, unnerving or uncomfortable situation places the Global Christian Church in a 'transitional' time between danger and opportunity (Bosch 1991:1) - between what was, but will ultimately not remain (and is rapidly disappearing) and what is, but is not yet fully developed.

This article will sound a clear call to the Western Church who ultimately now lives as 'exiles' in this globalised and urbanised world, calling them to a new urgent missiological reflection and then to a new glocalised ${ }^{5}$ togetherness within the cities of our world. In their new 'togetherness', the Christian Church needs to find a new way of being part of God's missio Dei unfolding in the realities of our time and our world.

Writer agrees with Shenk (Ott \& Netland 2006:9) that we have 'no choice but to recast knowledge and relationships in light of the processes of modern globalisation'. The Christian Church that hopefully is not 'otherwise engaged' is called to take note of what is really happening and should then in response take action. This call to the Christian Church will provide the answer to the question at the heart of this article: What should the Western Church do in the crisis it experiences within the reality of the context of globalisation and urbanisation?

\section{The first global reality: The whole world is moving}

The word globalisation may be new, but the process of globalisation has been going on for centuries. It is as old as humanity itself (Ferreira 2009:77). The dynamics of globalisation have been growing since the first nation 'lived near, traded with and battled another' (Sillis 2015:23). God himself set the movement of the people of this world in motion (see the table of nations in Genesis 10) when he confused the language of all the people gathered at the Tower of Babel (Gn 11). His redemptive focus on all the people and cultures of this world is clearly registered when he called Abraham (Gn 12) with the specific confirmation that God will bless all people through the new people (Israel) that he will gather. God's redemptive focus on the whole world then follows the contours of human history. The history of the world records the centrifugal phase of globalisation when the world's people movement was a movement away from the centre (where everything started) to the ends of the earth. In moving away from each other, people started to build walls and they erected barriers to isolate themselves, trying to keep themselves apart from

4.World Christianity - A very distinct new development of Christianity outside its original alliance with Western theological tradition.

5.Glocalisation (a portmanteau of globalisation and localisation) is the adaptation of .Glocalisation (a portmanteau of globalisation and localisation) is the adaptation of
international products around the particularities of a local culture in which they are international products around the particularities of a local culture in which they are
sold. The process allows integration of local markets into world markets - https:// en.wikipedia.org/wiki/Glocalization each other. It was the time of empires, power blocks and wars. In the New Testament, God's redemptive focus on the global world and all its people is again confirmed when Jesus Christ sends out his disciples as apostles to the ends of the earth (Mt 28; Acts 1). It is very clear that this command of Jesus Christ and the eventual happenings of Pentecost again reveal God's global focus and confirm that it should also be the focus of his church. It should not only be a possible horizon for human action, but should, in light of the reality of globalisation, now also serve as a platform from which Christian action spring. History confirms that the centrifugal phase of globalisation changed into a centripetal phase of globalisation when the interconnectedness of the global world grew and developed over time to eventually become an undisputed and overwhelming one unified global reality. As history unfolded, the speed, intensity and effect of the processes of globalisation just grew stronger. It became clear that the people of the global world need each other and that they started to focus on each other in a new way.

The historical development of globalisation may have taken several decades, but in a very short time - no more than a decade or two ago, everything changed. The global world opened up and swiftly became one global village. Different people and people groups moved (and are still moving) across the globe and the processes of movement are intensifying. Everything changed and is still in a process of constant changing. The world is now 'living in the midst of the greatest migration in human history' (Bakke 1999:225). People are moving from everywhere to anywhere. The results are overwhelming. We are fast becoming a borderless world (Medeiros 2013:183):

The British Empire once included 52 nations, but now all 52 nations live in London. France once ruled 46 countries, 26 African nations and another 20 countries on five continents -440 million French speaking people in very diverse places on five continents. Now all of those five continents are coming back to France. A hundred years ago the Germans built a railroad to the Bosporus. Now hundreds of thousands of Turks and many others from Eastern Europe are living in Germany. There are one million Japanese in Sao Paulo (Brazil). 80 million Chinese live outside of China. (Bakke 1999:226-227)

The continent of Africa is also experiencing its fair share of people movement, also called migration. It is very clear that migration is a complex process and there are different reasons for people moving away from their home countries. Political instability and tribal wars in Africa have contributed to a constant flow of refugees leaving their countries. Millions of people are displaced by famine and poverty. World economies are becoming more integrated and because of free trade agreements between different countries and cheap labour, people are moving to better their economic situation. Aging populations and low fertility rates in developed countries have been a pull factor for immigration into these countries. Former colonial empires are experiencing a flow of immigrants from the former colonies to the so-called 'motherland'. As borders became fluid and distances are no longer an obstacle, millions of people are prepared to move. 
It is also a reality in southern Africa. The new political dispensation in South Africa has created the expectation of new opportunities for people displaced in other African countries. Millions of people are taking the risk of migrating despite all the effort and hardship associated with it.

\section{The direction of the movement: The whole world is moving towards cities}

Globalisation and urbanisation have historically always been very closely connected. The movement of people and their eventual destination and habitation always corresponds. When we study the global movement of people more closely, it becomes evidently clear that the whole global movement is a movement towards the cities of the world:

People had been moving from the country to the city since about $3000 \mathrm{BC}$, when the first urban formations took shape in the Persian Gulf and soon spread across Asia and Europe. For the next 5000 years countless millions made the move to the city. (Saunders 2010:134)

Harvey Cox was already convinced in 1966 that future historians would record the 20th century as the century in which the whole world became one immense city (Cox 1966:273). The 21st century seems to be the final shift of human populations out of rural, agricultural life and into cities. This move is so significant that, according to Saunders $(2010: 1 ; 4)$ it will put an end to the major theme of human history, namely continuous population growth. That is the reason why he speaks of the 'modern arrival city as the product of the final great human migration' (Saunders 2010:21).

Within individual countries and also across borders of regions and continents, the whole people movement is towards the main urban centres. The globalisation process has integrated world economies that have linked the bigger economical hubs with each other. As rural economies struggle within a global market to support rural families in their local context, the expectation of better job opportunities in the cities is growing. Better medical services in the city benefit the birth rate and further stimulate population growth in the city. While the rural areas are more traditional and closed to outsiders, the cities are more diverse and seem to accommodate people more easily. The student population is also growing in the cities of the world. This leads to a growing urban cultural experience for the youth that will undoubtedly strengthen their permanent loyalty to the urban lifestyle.

In 2008 , more than $50 \%$ of the world's population lived in cities for the first time in history. It is estimated that by 2050, over $70 \%$ of the world's population will be living in cities. According to Mayur (Conn \& Ortiz 2001:17), 90\% of the earth's population will likely be urbanised by the end of the next century while much of this urbanisation will take place in 'super cities' in Developing countries. The situation is also very relevant for the African continent. Africa's urban population showed a $50 \%$ increase in just 15 years (Conn \& Ortiz 2001:65). Not only the cities in the global South are experiencing unprecedented immigration, it is also predicted that the 21st century will be the century of Africa's urbanisation (De Beer \& Swart 2014:2). Take note that Africa which has the world's highest urbanisation rate also struggles with the fewest resources to deal with it (Greenway \& Mashau 2007:7). It must be very clear that urbanisation has become unstoppable and irreversible.

\section{The second global reality: The centre of Christianity has shifted}

Against the backdrop of the global people movement and this movement to the world cities in particular, we must take note of Jenkins's urgent announcement: 'We are living through one of the transforming moments in the history of religion worldwide' (Jenkins 2002:1). Although Christianity is (still) growing globally, there is a very important and major shift in the places where these new Christians are to be found. They are no longer found in the places traditionally associated with Christianity. ${ }^{6}$ The situation changed dramatically in a very short time. In 1900, 82\% of the world's Christians lived in Europe and North America. In 2003 62\% lived outside Europe and North America. The main thrust of Christianity is now to be found in Africa, Asia, Latin America and Oceania (Barrett \& Johnson 2003). This is a very important fact that must be acknowledged and the importance and reasons thereof urgently explored. This is indeed a momentous phenomenon that cannot be missed in any way. Fact of the matter is that this major shift in the centre of Christianity has an important message that must be heard. It announces the end of Christendom and the commencement of World (global) Christianity.

\section{The end of Christendom}

Christianity originally developed within the folds of Western culture and later became known as 'Christendom'. Christendom is the name given to the religious culture that has dominated Western society since the fourth century ${ }^{7}$ (Frost 2006:4); it was the 'faithful replication of Christian forms and patterns developed in Europe' (Sanneh 2003:22). It is undeniable that for 400 or 500 years the fortunes of the Christian Church and the people of Europe ${ }^{8}$ were intimately intertwined. For many decades, Christianity had a very privileged position within Western culture and the history of the Christian Church in the Western world was intimately linked to the history, development and expansion of Western culture. According to Falk, the two flowing streams of Western colonialism and Christianity were even seen by the West as the 'confluence of civilization and Christianity'

6.Traditionally, Christianity was found in the Western world - Europe and North America.

7.Time of Constantine when Christianity became the preferred religion of the Roman Empire.

8.It is also true of their offspring who went to other countries of the world. Specific attention is drawn to the people who have left Europe to settle in South Africa since 1652. They have been planted as Western or Christendom Church in south and
165ing Southern Africa. 
(Conn \& Ortiz 2001:61). In 1920 Hillare Belloc wrote that 'The Church is Europe and Europe is the Church'.

But, this epoch in history called Christendom has, according to Frost, 'crashed like a wave and has left the Western Church' high and dry' (Frost 2006:3). Modern Western culture (called modernity) became highly critical of religion and increasingly secular in its assumptions. Religion was eventually banished to the 'backwaters of modern culture' (Bosch 1991:vii). Bosch describes it as the West turning its back on the gospel (Bosch 1991:58). The fact is that Christianity was rejected in contemporary Western societies (Escobar 2003:74). Western culture abandoned Christianity and pushed it from a very privileged position at the centre of Western society to the margins of the community and the private lives of individual believers. This led to the rapid demise of Christendom and the rise of a post-Christendom reality within the Western world. We now have to face the reality that Christendom is dead and that it is also dying in other places. Much of Europe is now culturally and religiously post-Christian (Ott \& Netland 2006:23). As a sociopolitical reality, Christendom has been in decline for the last 250 years. That is the reason why contemporary Western culture has been called by many historians (secular and Christian) the post-Christendom culture (Frost 2006:5). With deep grief, it must be admitted that Christendom will not be saved and therefore we need to conclude that the Christendom era has fallen (Frost 2006:7). That is the reason for the critical assumption that the Church in the West is indeed in deep trouble (Dowsett 2001:448).

\section{The formation of World or Global Christianity}

While the North Americans (and other contexts where the Western Church is found) are still living under the delusion ${ }^{10}$ that the age of Christendom has not passed (Hall 1997:19-20), Christianity as a religion is now thriving in the South. According to Walls, 'the period (since 1792) has seen the Christian centre of gravity steadily move away from the West and towards the Southern continents' (Walls 2002:31). Christianity is growing as a world religion. What is at issue now, according to Sanneh, is the 'surprising scale and depth of the worldwide Christian awakening that seems to proceed without Western organisational structures, including academic recognition'. It is also occurring in the midst and in the context of widespread political instability and even in the face of the collapse of public institutions. It can even be called 'a post-Western Christianity' (Sanneh 2003:3). What is really happening is still very much a mystery, because it is not really the focus of an in-depth and comprehensive theological research (yet). Even church leaders and theologians from the Western Church have been unable to comprehend fully, and also understandably, to respond effectively to the scale of this new reawakening of Christianity. The situation is however slowly changing and the Western Church is slowly waking up to the 'seismic shift in Western Christianity' (Unknown 2014)

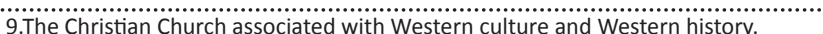

10.This is my concern that the Christian Church in the Western world is still 'otherwise engaged' as if it is still 'business as usual' - not really acknowledging the depth and urgency of what is really happening. and will eventually realise the importance of the transitional times that we are experiencing.

This means that the average world, Christian is no longer a middle-class, middle-aged, Caucasian, North American man from a mainline Western denomination. The average world Christian today looks more like an 18-year-old, Developing World female believer from an independent, charismatic denomination, living in an impoverished community in the Developing World. The 20th century undoubtedly saw a radical shift in the Christian world and we are now confronted with an increasingly diversified Christian Church.

We are now seeing a new and fresh resurgence of Christianity, called the formation of Global Christianity. It is also called the formation of the 'Third Church, the Southern Church' (Jenkins 2002:3). Although this shift in the centre of Christianity is an undeniable fact, the shift is not yet fully complete. But, according to Buhlmann, "The Southern Church is the Church of the future as well as the future of the Church' (Bediako 1995:128). For the purpose of the Christian churches' mission in this world, Christian unity must find a new glocal expression to really be relevant in the rapidly urbanising world we are confronted with.

\section{The need for urgent missiological reflection: Why is this happening?}

In facing this new global reality, we need to ask the following questions. Why is this happening? What would be the reason(s) why God is allowing the history of our world and Christianity to develop in such a way? As Christians, we also need to ask how this new reality reflects on God's missio Dei. If this is part of God's mission (and the answer is undoubtedly affirmative), how does it impact on the mission of God through the Christian Church in this new globalised world?

It must be acknowledged that this is without any doubt a Kairos moment in the history of the world and of Christianity. Christianity in its new formation is already and ultimately will be looking different in future; Christendom will not be saved and the Christian community already 'faces a new urban generation' (Conn \& Ortiz 2001:22). It is a completely new and confronting reality that is correctly described by Bosch (1991) as a 'fundamental paradigm shift' and a 'crisis'. He (Bosch 1991) continues:

There have been profound crisis and major paradigm shifts before. Each of them constituted the end of one world and the birth of another, in which much of what people used to think and to do had to be redefined. (p. 4)

But, to still quote Bosch: 'Crisis is the point where danger and opportunity meet' (Bosch 1991:7). The church as the body of Christ was always meant to become a global community. The Bible is very clear on God's Kingdom purpose for his church in this world. God always had the whole world and all people in focus. Embedded in God's 
very particular dealing with his people (Israel) was a very clear 'universal intention' (Ott \& Strauss 2010:7). The purpose of Abraham's call (and therefore Israel's and the church's) is linked to the well-being of the nations (Ott \& Strauss 2010:8). This is confirmed by Jesus Christ after his resurrection and just before his ascension (Mt 28: Acts 1). It is clearly initiated with what happened at Pentecost (Acts 2). It is also very clearly taught by the apostle Paul when he speaks of God's 'mystery revealed' in his life 'as never before' (Eph 3:1-6). In the words of Ridderbos (Quoted by Conn \& Ortiz 2001:151), 'The great framework of redemptive history has arrived at its turning point in Jesus' coming. And it will reach its final turning point in his coming again'. They elaborate further: 'Between these two turning points runs the course of urban mission' (Conn \& Ortiz 2001:151). God's focus was on the global world and all people. The apostle Paul explains it again in Acts 17 to the people of Athens. God's redemptive focus and his kingdom purpose follow the contours of the history of this world:

From one man he made every nation of men that they should inhabit the whole earth; and he determined the times set for them and the exact places where they should live. (Acts 17:26)

\section{An end that is also a new beginning}

What we call globalisation is clearly more than a historical process. It can be described in secular terms where economics not only is at its heart but will also be the future organising principle (Escobar 2003:56). However, it should not only be explained as a purely human and worldly phenomenon; as the product of market forces only. In Acts 17, it is (again) made perfectly clear that God is in full global control of everything that happens with all people everywhere. He is in control of people's movement, their habitation and the time they have to spend in a certain place. In light of God's redemptive global focus recorded in the Biblical narrative, it must be clear that God has a purpose with and in the processes of globalisation. While we may not always have specific clarity to that purpose in a very specific situation, he will not permit his purpose to be thwarted. Globalisation is not simply a product of a human desire for betterment, a working out of aggression or even a flight from danger. Rather God himself orchestrates the globalising phenomenon of human migration:

The fundamental fact of population migration, the presence of people of many cultures living together the world over, is not a theological problem. It is a phenomenon we are called to embrace and even to engage. (Pocock, Van Rheenen \& McConnell 2005:30)

This writer is in complete agreement with Bosch when he confirms that 'the Christian church is always in a process of becoming; the church of the present is both the product of the past and the seed of the future' (Bosch 1991:422). The Christian Church of our days must prayerfully determine its place on God's redemptive timeline within the history of this world. When we are (again) reminded of God's complete control, there is indeed real hope as expressed by Frost (2006:7): 'the end of this epoch actually spells the beginning of a new flowering of Christianity'.

\section{God's call to exiles}

The modern globalising world is indeed a confusing reality for the church of Jesus Christ. The Western Church, in particular, is experiencing a world that has become quite foreign. In some way, the culture that the Christian Church helped to form abandoned the church to a world that became completely secularised. It may feel, according to Kaldor's description, as if the church is now part of 'a village church in an urban prison' (Conn \& Ortiz 2001:234). Greenway speaks of 'Protestantism's perennial urban despair' (Greenway 1974:13). Frost is also trying to describe it by saying: 'Christians are falling through the cracks between contemporary secular Western culture and a quaint oldfashioned church culture of respectability and conservatism'. He continues: 'Christians feel "a nagging tension of being at home neither in the world nor in the church as they've known it"' (Frost 2006:3):

The death of Christendom removes the final props that have supported the culturally respectable, mainstream, suburban version of Christianity. This is Christianity expressed by the Sunday Christian phenomenon wherein church attendance has very little effect on the lifestyles or values expressed from Monday to Sunday. (pp. 7-8)

This is the struggle of the Western Church in a post-modern and post-Christendom world. In some way, it echoes the plight of Israel as exiles in Babylon in Old Testament times. The Jewish people in exile also struggled to find a purpose in their new and foreign circumstances. They were so confused and destitute that they even wanted to stop their singing of God's praises according to Psalm 137. They also experienced their situation as something gone terribly wrong. God provided them with a very clear answer. The Old Testament scholar Walter Brueggemann (1997) finds a parallel between the contemporary Christian experience of dislocation, uncertainty and irrelevance and the experience of the Old Testament Jewish exiles in Babylon. Frost agrees that the experience that faced the Jewish exiles in Babylon mirrors the church's experience today (Frost 2006:9). Just like the Jewish exiles, the church today is grieving its loss and is struggling with humiliation. But, God has answered them. He has provided all believers in all ages with a relevant answer and the strength to persevere. The Bible clearly recalls different ages, wherein believers struggled in difficult circumstances. They survived and ultimately kept their faith alive (see Heb 11). God's Word will also guide his exiles or pilgrims within the Western Church in these confusing times. In Jeremiah 28-29, the Western Church should also learn from God's call to exiles.

\section{A call to reconfirm their identity}

God is calling his people in exile to reconfirm their identity as his chosen people within the very context of their present life and sufferings. They were displaced by God himself with a very specific purpose. God used the exile to correct his people's missiological focus and their missional ministry. $\mathrm{He}$ clearly commands that their thinking and attitude should not 
be informed by the self-preservation agenda of the everpresent false prophets, but by God's clear call to a long-term commitment and a sacrificial lifestyle he demands of them in their specific context. God's people are therefore not victims of their situation - they are missionaries sent by God to work in that specific context.

The Western Church should also be urgently reminded of God's continued presence in and purpose for their existence even if their world has changed completely. We, as Christians in a post-modern and post-Christendom world, must be reminded that we are God's missionaries. Today, the Christian stance in the West has to become a missionary stance. To be a Christian is equivalent to being a 'resident alien' (Escobar 2003:73). Van Engen has written a very important book and focuses on the church as 'God's missionary people' (Van Engen 1991). When David Bosch wrote his seminal work 'Transforming Mission' (Bosch 1991), he wanted to contribute to a 'new believe in the future' by reminding us again of the Biblical understanding of the role of the church in our new world. He quoted Hoekendijk (Bosch 1991:9) by saying 'The entire Christian existence is to be characterised as missionary existence'.

\section{A call to develop an urban theology}

God's call to the exiles is clearly a call to an urban theology and then an urban mission and ministry. The exiles had to focus their prayers and the whole of their missional presence to benefit the city of Babylon. This implies a very specific ministry focus that will involve their whole being. It should become their lifestyle. It was clearly something that the people of Israel lacked completely while they were still living in Canaan. In their new situation, they are called by God to be diligent in their efforts (seeking) to really establish something that was completely new to them at that moment. Their serving others was in fact, them serving him. It was not a fleeting and short-lived endeavour or project, but a total life commitment that they had to adapt willingly to.

It is obviously clear that the Western Church was, during Christendom times, never really at home in the developing urban context of the Western world. Christendom was originally founded in a rural European setting and never really came to grips with the urban realities that developed. When the Western world started urbanising, the Western Church sub-urbanised ('suburbia is a reaction to the city - an attitude - a mind-set') (Greenway 1974:107) and started to flee the heart of the city. Bakke calls this a sign of the 'cultural captivity' of the Western Church; 'white fright, white flight' (Bakke 1997:21). The Western Church abandoned the city. Maybe this is one of the reasons for the demise and eventual death of Christendom. Greenway has also convincingly written about the fact that 'Protestantism'11 was never really at home in the city (Greenway 1974:100). He also concluded that it was 'painfully clear that Protestants in the city are still wringing hands and wondering what they should do' (Greenway 1974:101). For Bakke, the greatest crisis he faced 11.The Western Church coming from 16th-century Reformation. in his ministry was a theological crisis. He did not have a theology that addressed the (urban) world that he was experiencing (Bakke 1997:22). Urban realities require that Christianity develops an agenda that addresses more than church planting or evangelism (Conn \& Ortiz 2001:21). The church should not only do mission in the city but also mission for the city (Conn \& Ortiz 2001:25). It never really happened. Only through developing a constructive urban theology will the Western Church effectively counter the 'inherited theological reluctance' of Christendom towards urban ministry (Conn \& Ortiz 2001:23).

\section{A call to seek God's shalom for the city}

What does it really mean? What should be the specific focus and eventual content of urban theology? It is clear that God does not want his people to concern themselves with their own survival, mere maintenance or an agenda of selfpreservation. He is very clear in denying the false prophets that are speaking to the exiles nostalgia and self-preoccupation. God's command is not propagating a quick fix for his people only, but a comprehensive holistic focus that include everybody. It will undoubtedly require substantial personal effort, focus and sacrifice from God's people. All those things that they wish for themselves, they should endeavour to provide for all the others too. Only when they give and empower the others - will they themselves receive from God. It is all about life as God intended it to be. It clearly affects living conditions and personal and adequate security (the building of homes); enough food to eat; food security on the long term (planting of gardens); family life that is conducive to all growth potential for the future (to have children and to even let them marry); to foster strong and peaceful relationships (growth in number of people and a healthy and safe environment). Shalom is exactly the positive opposite of what we normally experience of an urban environment. They were called to be God's city (the idealised city where God reigns - Jerusalem) within the city of Satan (Babylon) (Ps 122:6-9; Ps 147:2) (Linthicum 1991:24-25).

In current missiological terms, to seek the welfare of the city (God's shalom) can be described as community transformation. According to Priest, the goal of community transformation is:

1. to restore people to a full expression of their humanness as made in the image of God;

2. to promote trusting, reconciled and just relationships with people;

3. to form communities that have a shared vision, a sense of community;

4. to create new institutions and restore existing systems and structures; and

5. to seek God in all that we are and do, so that God's kingdom and glory may become more present on earth as it is in heaven. (Priest 2012:n.p.)

Saunders (2010) surprisingly and unexpectedly expresses a very positive view on the processes of urbanisation. He clearly reflects God's positive view of the city as communicated in Jeremiah 29. Saunders identifies a special 
kind of urban place. He is referring to 'transitional spaces' which he calls 'arrival cities' (Saunders 2010:4). These arrival cities have a very important function in our world and they are 'at the centre of the world future' (Saunders 2010:58). As Christians, we should endeavour that these arrival cities should not function as mere 'survival cities', but that they become 'revival cities' (Saunders 2010:311) - 'kingdoms of the marginal' (Saunders 2010:314) but also 'gateway cities' (Saunders 2010:314) with a 'culture of transition' (Saunders 2010:317) to help people moving forward and upward in their urban journey.

\section{A call to a new glocal ${ }^{12}$ togetherness}

God's call to the exiles to live in a new way and commit their whole existence sacrificially was not God's suggestion for some, but his will for all. It is very clear that it cannot and should not be the effort of some individual believers, but that it should be the collective response to God's will in the life of every urban believer within the specific context where they live and work every day. It is not everyone for himself (the individualism of Western culture) but all collectively serving God. This calls for a new focus on the 'community of the saints' - the believers living and working together in a new 'koinonia'. Christians are called to live in unity - the unity that God has already made a reality through Jesus Christ.

One of the problems experienced within Christendom was the fact that the Christian faith was culturally individualised and privatised. This is referred to as the eventual 'cultural captivity' of the Christian faith. This is another reason why the time of Christendom has passed. God is now calling the Western Church to a new contextual theology wherein context, community and mutual participation in God's mission should be in every Christians focus and practical lifestyle. This new contextual focus of a new 'theology from below' constitutes 'an epistemological break' with traditional theologies (Bosch 1991:423) but redirects and intensifies the church's missional response to the new urban context that is the new and final frontier of mission.

\section{Going forward together}

The Western Church (and Western theology) must urgently be awakened to the new reality that is in danger of passing it by. It must re-examine itself in light of God's urgent call to exiles to reaffirm their missional obligation within his redemptive (current) global timeline. They should not be 'victimized by nostalgia' or be 'buffeted by fear' (Frost 2006:9) to only focus on self-preservation, maintenance or survival, but should start to believe in God's future (Bosch 1995). The Western Church must be awakening to its missional responsibility to a culture in crisis (Neely, Pipkin \& Shenk in Bosch 1995:viii). The Western Church cannot ignore the sociopolitical issues of its own context and neither can it ignore the Developing World (Bosch 1995:35). ${ }^{13}$ This is especially true for the Western Church in South Africa that is still immobilised (and traumatised) by the not yet resolved after-effects of 'apartheid theology' that impacted negatively on its ministry within its very unique African context. Bosch is absolutely correct in his insistence that the Western Church should include the Developing World (and the Third Church - IWF) when talking missiologically about the West (Bosch 1995:36).

We must admit that our theological reflection on urban mission, especially in the African and South African context is very limited. What Linthicum admits for the context he knows is also applicable for the situation in South Africa. He admits to entering the city not only 'equipped with an urban sociology and urban tools for ministry' but also with 'the baggage of a theology designed in rural Europe' (Linthicum 2005:20). This places the biggest challenges or barriers to our proposed urban mission in the church itself (Bakke 1999:234; Keller 2013:104). That is the very reason why the Western Church in so many ways in the past did not take advantage to the phenomenon of urbanisation (Baker 2009a:19). The Western Church will intentionally have to do something that it not only failed to do in the past but also will struggle to implement in the present and future because it will have to face its strongest resistance from within itself. Bakke (1999) describes this very big challenge in the following words:

Mission is forcing us to re-invent the church and to rethink theology and mission practice. Having been in and around seminaries for 30 years, I can assure you that we are not ready for this ... Our seminaries are autobiographically preparing people to move into the narrow stream of whiteness and middleclassness, but while that remains a major stream of Americana, it comprises only 13 per cent of God's earth ... Eighty-seven per cent of our world is non-white ... Seminaries have done well at being the memory bank of the church, far less well at being the research and development unit for the future. (p. 230)

The Western Church, therefore, needs the Southern Church in order to 'rediscover Christianity without the Christendom framework' (Murray 2004:184). In this way, it is an opportunity for the church to (re)discover itself in the way Christ intended it to be from the very beginning. In the words of Andrew Hall (1997):

We must stand off from the liberal middle-class culture with which we have been consistently identified; rediscover our own distinctive ontological foundations and the ethical directives that arise from them; and allow ourselves, if necessary, to become aliens in our own land. (p. 54)

The Southern Church also needs the Western Church in order for them to be very cautious not to be enslaved by the new popular culture (again). They must learn not to develop a new culturally captive 'Christendom'. It must be a 'going-forwardtogether' - because in the cities the Global Christian Church will not only discover people who are coming from a preChristendom context but also people coming from a post-

13.It is exactly within this Developing World context that the 'Third Church' - the Southern Church is growing. For the Western Church to still be part of future global Christianity, it must reach out and move towards what is happening there. 
Christendom context. This focus is confirmed by Ortiz when he also, among other things, highlights some specific implications for missions in this time (Ortiz 2006:11-14). It must be 'city centred and globalized'. It must also be 'intentionally ecumenical in the way that mission should be done in partnership'.

\section{Conclusion Going forward in hope}

Like Thomas Friedman, we have to admit that the world around us changed 'while we were sleeping'. Well, not actually sleeping, but we were also 'otherwise engaged' - busy with something else - maybe only business as usual - caught up and trapped in a Western culture that already pushed Christianity to the margins of society. But God is not sleeping. The missionary God is going where he is needed (Yancey quoted by Jenkins 2002:15) and his missio Dei is still moving across this world on its way to the end of time. God is now focusing on the ends of the earth that are actually now been gathered in the cities of the world. Praise God - the so-called unreached people have become reachable. The relevant question for our time would be: Does God's present global and urban mission have a church? Although the Christendom story no longer defines Western culture in general, it (still IWF) remains the 'primary definer of the church's self-understanding in almost every Western nation' (Frost 2006:5). Bosch is willing to pardon our 'spiritual forebears' for not having been aware of the fact that they were facing a crisis, but he is not so lenient towards our present generations. They can 'hardly be excused for their lack of awareness' (Bosch 1991:7). Christendom has played a major role in the formation of the Western city. The new resurgence of Christianity in the Developing World - in full cooperation and collaboration with the Western Church in exilic reawakening - also needs to be involved in the formation of African urbanism. To really impact the growing African city, call on the church of Jesus Christ. It is already sent and will be equipped by God. The Western Church should (and can IWF) engage the future with hope (Smith 2011:42-47). This hope was communicated by Roger Greenway (1978:11) when he concluded: 'At no time in history has it been more true than now, that he who wins the city, wins the world'.

\section{Acknowledgements \\ Competing interests}

The author declares that he has no financial or personal relationships that may have inappropriately influenced him in writing this article.

\section{References}

Baker, S., 2009a, 'Introduction: Globalization, urbanization and mission', in S.S. Baker (ed.), Globalization and its effects on urban ministry in the 21st century, pp. 1932, William Carey Library, Pasadena, CA.

Baker, S.S., 2009b, Globalization and its effects on urban ministry in the 21st century, William Carey, Pasadena, CA.

Bakke, R., 1997, A theology as big as the city, InterVarsity Press, Downers Grove, IL. Bakke, R., 1999, 'Urbanization and evangelism: A global view', Word and World XIX(3), $225-235$.
Barrett, D.B. \& Johnson, T.M., 2003, 'Annual statistical table on global mission 2003', International Bulletin of Missionary Research, 27, 24-25. https://doi.org/ 10.1177/239693930302700106

Bediako, K., 1995, Christianity in Africa. The renewal of a non-western religion, Orbis Books, Maryknoll, NY.

Bosch, D.J., 1991, Transforming mission. Paradigm shifts in theology of mission, Orbis Books, New York.

Bosch, D.J., 1995, Believing in the future. Toward a missiology of western culture, Trinity Press International, Harrisburg, PA.

Brueggemann, W., 1997, Cadences of home: Preaching among exiles, John Knox, Louisville, KY.

Conn, H.M. \& Ortiz, M., 2001, Urban ministry. The kingdom, the city and the people of God, 1st edn., InterVarsityPress, Downers Grove, IL.

Cox, H., 1966, The secular city: Secularization and urbanization in theological perspective, SCM Press, London.

De Beer, S. \& Swart, I., 2014, 'Towards a fusion of horizons. Thematic contours for an urban public theological praxis-agenda in South Africa', HTS Teologiese Studies/ Theological Studies 70(3), 9. https://doi.org/10.4102/hts.v70i3.2812

Dowsett, R., 2001, 'Dry bones in the west', in W. Taylor (ed.), Global missiology for the 21 st century. Reflections from the Iguassu Dialogue, pp. 447-462, Baker Academic, Grand Rapids, MI.

Escobar, S., 2003, A time for mission. The challenge for global Christianity, Inter-Varsity Press, Nottingham, England.

Ferreira, I., 2009, 'Globalization. Africa, the church and it's mission', in S.S. Baker (ed.), Globalization and it's effects on urban ministry in the 21st century, pp. 75-85, William Carey, Pasadena, CA.

Friedman, T.L., 2006, The world is flat. The globalized world in the twenty-first century, Penguin Books, London.

Frost, M., 2006, Exiles. Living missionally in a post-Christian culture, Hendrickson Publishers, Peabody, MA.

Giddens, A., 2002, Runaway world. How globalisation is reshaping our lives, Profile Books Ltd., London.

Greenway, R.S., 1974, Calling our cities to Christ, Presbyterian and Reformed Publishing Company, Nutley, NJ.

Greenway, R.S., 1978, Apostles to the city, Baker Book House, Grand Rapids, MI.

Greenway, R.-S. \& Mashau, T.-D., 2007, An eye that sees. Vision for urban missions, ThitshiProductions, Potchefstroom.

Hall, D.J., 1997, The end of Christendom and the future of Christianity, Trinity Press International, Valley Forge, PA.

Jenkins, P., 2002, The next Christendom. The coming of global Christianity, Oxford University Press, Oxford.

Keller, T., 2013, 'What is God's global urban mission?', in S.T. Logan, Jr. (ed.), Reformed means missional, pp. 97-109, New Growth Press, Greensboro, NC.

Linthicum, R.-C., 1991, City of God, City of Satan. A Biblical theology of the urban church, Zondervan Publishing House, Grand Rapids, MI.

Linthicum, R.C., 2005, Building a people of power. Equipping churches to transform their communities, Worldvision, Waynesboro, GA.

Medeiros, E., 2013, 'God scatters to gather through his people. A missional response to migrant churches', in S.T. Logan (ed.), Reformed means missional, pp. 173-188, Green Growth Press, Greensboro, NC.

Murray, S., 2004, Church after Christendom, Paternoster, Colorado Springs, CO.

Ortiz, M., 2006, Globalization, the city, the church and its mandate to minister to the urban poor, Johannesburg, Unpublished.

Ott, G. \& Netland, H.A., 2006, Globalizing theology. Belief and practice in an era of world Christianity, Baker Academic, Grand Rapids, MI.

Ott, G. \& Strauss, S.J., 2010, Encountering theology of mission. Biblical foundations, Historical developments and contemporary issues, Baker Academic, Grand Rapids, $\mathrm{MI}$.

Pocock, M., Van Rheenen, G. \& McConnell, D., 2005, The changing face of world missions. Engaging contemporary issues and trends, Baker Academic, Grand missions. Engd
Rapids, Ml.

Priest, D., 2012, Seek the Shalom of the city, viewed 06 March 2015, from http:// newurbanworld.org/seek-the-shalom-of-the-city/\#_ftn2

Sanneh, L., 2003. Whose religion is Christianity? The Gospel beyond the West, Wm. B Eerdmans, Grand Rapids, MI.

Saunders, D., 2010, Arrival city: How the largest migration in history is reshaping our world, Random House eBooks, s.l.

Sillis, M.D., 2015, Changing world, unchanging mission. Responding to global challenges, Inter Varsity Press, Downers Grove, IL.

Smith, D.J., 2011, Seeking a city with foundations. Theology for an urban world, InterVarsity Press, Nottingham.

Unknown, 2014, Generations with vision, viewed 04 May 2015, from https:// generationswithvision.com/2014/the-seismic-shift-in-western-christianity/

Van Engen, C., 1991, God's missionary people. Rethinking the purpose of the local church, Baker Book House, Grand Rapids, MI.

Walls, A., 2002, The cross-cultural process in Christian history, Orbis, Maryknoll, NY. 